\title{
Analysis on the Innovative Practice teaching of industry - university Interaction for Network and new Media Major
}

\author{
Jun Yu \\ Xi'an Eurasia University, Xi’an, Shaanxi, China, 710065
}

Keywords: Innovative Practice, Network and New Media, Teaching Innovation.

\begin{abstract}
Network and new media professional is based on the Internet and other emerging media form of the news communication industry and the whole society a huge push, conform to the digital information age development needs, conform to the mobile Internet era of media convergence trend requirements arising from the new class of news communication. From the Ministry of Education in 2013 approved professional enrollment so far, the colleges and universities in the professional practice of teaching to find their own characteristics, the professional application of the characteristics of the teaching are generally recognized; and application-based undergraduate professional is based on industry demand objectives, the school for the enterprise Cultivate talents, pay attention to the cultivation of students' ability to work and their application to knowledge. So, "industry interaction" has become the inevitable choice of professional practice teaching.
\end{abstract}

\section{Introduction}

Network and new media professional as a new professional practice teaching with the advantages of innovation, compared with the traditional professional there is no "burden", the development of the new media industry is not the traditional media system "restrictions", the two sides have a good interactive conditions. Participate in the interaction between schools and enterprises have their own advantages, the two sides co-commitment to personnel training, in order to achieve complementary advantages, interactive win-win situation. Colleges and universities have the advantages of intelligence, knowledge and scientific research, enterprises have a platform and practical advantages. The implementation of industry-university interaction, both in the production and teaching and research level to communicate, so that college students and teachers have the opportunity to participate in the practice of enterprises; enterprises can also participate in university curriculum construction, teaching plan development and training objectives set. On the other hand, the practical ability of school students and teachers has been improved, the school itself can also get the enterprise Of the talent needs information, so that professional schools keep up with industry trends. Industry and the interaction, its essence is to enable students to learn the school in the knowledge and practice of business combination, so that the school's intelligence and business equipment, technology to achieve resource sharing, complementary advantages, in order to effectively improve the school's targeted and practical To improve the quality of application-oriented talents. However, there are some problems in the interaction between universities and universities. If the government is not strong enough, the policies and safeguards are not in place, the degree of enterprise participation is not high, and the depth and breadth of school-enterprise cooperation is difficult to achieve the expected effect. Personnel training quality, professional construction, employment rate and the quality of employment are difficult to point to the surface of the two-way combination of multi-level and full-service social unity of the community; the ability to serve the regional economy and school-enterprise sustainability cooperation also There is a lot of uncertainty. Therefore, as a new network and new media professional to effectively carry out industry-university interaction, innovative talent training model. 
It should focus on the following aspects to solve the problem: First, the leading role of the government can not be missing, to introduce the participation of personnel training enterprises and schools to support funding and policy safeguards. Second, enterprises should mobilize the role of the enterprise to participate in the initiative, take the initiative to cultivate talent to create high-quality practice platform. Third, the school should improve the teaching management system, timely introduction of double team construction support program. Fourth, schools and enterprises should jointly strengthen the combination of professional construction and industrial development, teaching reform and project research and development, training certification and employment promotion approach. Fifth, in the process of personnel training, both schools and enterprises should deepen the research on the quality of personnel training and the improvement of social service ability.

\section{Innovative Mode of Practical Teaching in Production and Learning}

It is necessary to constantly improve the practice teaching environment, explore the new system of practical teaching, build a scientific and perfect practice management mechanism, realize the mutual appointment of employees and expand the number of school-enterprise cooperation units, Improve the level of cooperation. Generally summed up, the following models can be achieved:

First, the school experimental teaching center model. Colleges and universities based on their own network and new media professional training program, set up experimental teaching center, relying on professional laboratory to complete teaching tasks. Common laboratory names include new media labs, converged media labs, and network communication labs. These laboratories on the one hand to undertake the professional training programs in the curriculum of teaching tasks, on the other hand also take the network and the new media professional skills training tasks. In the curriculum design, teachers can teach and practice organic combination, change the traditional experimental course teaching methods, so that teaching in the training to complete. There are some colleges and universities with the enterprise to build a laboratory model, enterprises for college investment funds or equipment to establish a laboratory, training teachers or teachers. This model for professional practice teaching, is more effective form of interaction between school and enterprise, but not all colleges and universities can be achieved.

Second, the school practice teaching platform model. Colleges and universities based on the actual needs of the network and the new media professional, comprehensive planning, the progressive implementation of the development of practical teaching platform. Common forms of new media center, website, network communication training center, data news studio and so on. The establishment of this platform allows schools to carry out students' innovative ability training and production practice training on a fixed practice teaching platform. Schools to establish an effective platform for innovation and practice for students to provide practical places; at the same time open to the enterprise, part of the teachers and students can be completed by the enterprise project can be introduced to the school practice platform for college teachers and students to participate in corporate practice. This is the enterprise, can save the project manpower cost; for colleges and universities, the campus practice platform can be more applied value. In short, is conducive to improving the integration of enterprises and colleges and universities of the enthusiasm.

Third, the practice of teaching base outside the model. Universities and cooperative enterprises in the complementary advantages of the principle of common development, clear responsibilities of both sides, investment in certain funds, enterprises listed in the establishment of training base in colleges and universities. Common forms of training teaching base, teaching practice base, to "production, learning, research" integration as the goal, the establishment of off-campus training base, broaden and strengthen the practice base outside the school. Through the internship training base, students can directly participate in all aspects of production or management, is conducive to improving students to adapt to social needs and development of the application capacity. At the same time, to further deepen the depth of interaction between school and enterprise, so that enterprises have the opportunity to enter the school, close to feel the school, take the initiative to accept the practice of teachers and students, learning the integration model; schools should seize the 
opportunity to take the initiative to use the advantages of the school service Enterprise construction, take the initiative to provide enterprises with intellectual training, participation in enterprise technology research and development, so that enterprises in the technical upgrading and equipment updates have sufficient intellectual support.

\section{Implementation of Interactive Practice Teaching Points}

As a systematic project, the network and the new media comprehensive practice teaching workshop can not be separated from the following elements of the careful design and cooperation with each other:

Course system settings: according to local conditions, to complete the substantive transformation. Network and new media professional training programs, whether the curriculum system is scientific and reasonable, can correctly handle the pre-theoretical courses and post-practice courses between the proportion of setting and content convergence, whether to complete the existing experimental teaching, case teaching, simulation Teaching and other teaching methods of upgrading and transformation ....... will eventually affect the late comprehensive practice of the quality of the workshop. In recent years, the domestic university network and new media professionals are in line with the industry development trend and their own resources accumulated efforts for their own tailor-made scientific teaching mode and curriculum system. In this regard, Zhang Qin summed up for the three models: emphasis on the journalism of the Chinese people's university model, advocating technicalism of the Wuhan University model, and respected communication of the Fudan University model. On this basis, I red and so add the network editor, digital media art two talent training mode. Regardless of what kind of model, can not be a simple transformation of the traditional news communication, should reflect the network and new media professionals training technology, application and complex and other characteristics, or not only professional development prospects are not optimistic, and difficult Comprehensive teaching workshops provide solid knowledge support. Field support: the new media laboratory to promote the benign operation of the workshop. Network and new media comprehensive practice teaching workshop to achieve real innovation is the key point of the relevant laboratory construction. As mentioned earlier, the rapid development of new media network, and promote the formation of the media integration ecology, which requires new media personnel must have cross-platform communication capabilities. So how will this industry, the market demand for professional ability to land? How can the talented development plan be implemented? How to match the practical teaching and ability requirements? New media laboratory construction is particularly important. This space, site and conditions of the design and arrangements can also become a break the original professional structure framework, conform to the development of the times, a breakthrough in market demand. In this regard, the Sichuan Institute of Foreign Languages Institute of Journalism and Communication conducted a useful exploration, they pointed out that the laboratory should first be able to meet the various media practice ability of basic training, such as print media interview report editing section, television media interview report editing class, Practice class, network media skills classes, so that students do a multi-skilled. On this basis, to build financial media experimental platform to achieve the printing, print, visual and online media, the integration of various media resources, so that students in the simulation of the media environment for the integration of media learning and practice, and strive to do with the industry mainstream A seamless form of media.

There are studies of student workshops can be summarized as: into a team, sub-topics; student guide, teacher analysis; with the growth, a total of progress. But this is only the external organization of the workshop, this shallow description can not cover the workshop more important content design and operation arrangements. Network and New Media is an interdisciplinary subject designed to cultivate new types of information production, processing, communication and digital marketing applications, and compound talents. To strengthen the professional ability of students, especially the cultivation of comprehensive practical ability is both professional logic, but also a strong voice of the social market. Therefore, the ability to guide and enhance the level of students to solve practical problems, it has become a network and new media comprehensive practice teaching 
workshop operation of the logical starting point and destination. In this area, we pay special attention to the most practical measurement workshops in the practice teaching of Hong Kong's engineering surveying practice. The model is guided by capacity-building, which is subdivided into three modules. Each module corresponds to a number of competency elements and tasks that need to be completed. Each task corresponds to a number of knowledge units. And its practice workshop runs through three years of personnel training process, and in accordance with the ability level from low to high step by step design; the same time, the model is another feature is based on "ability task - clearance issues - knowledge unit" design concept in Each of the promotion process set up the corresponding clearance issues, these problems can be a good convergence ability elements and knowledge units. In addition, the workshop on the student's assessment throughout the implementation of the project throughout the process, the teacher through the stage for each student's results and the final completion of the project to score a comprehensive score. The workshop also emphasizes and records students' records of the learning log, which requires students to record their own problems, perplexities, experiences and contributions during the course of the study, so as to facilitate the exchange of teachers and students to help teachers control the situation.

\section{Conclusion}

Network and new media comprehensive practice workshop designed to conform to the media development trend of the times, is to solve the theoretical teaching and practice teaching out of touch, ability training and practice teaching does not match the traditional examination mode and practice teaching is not matching problems. As a system engineering and complex process, its good operation needs to break the media as a standard distinction between professional settings and personnel training practices, but also need to melt the media laboratory as a platform and a breakthrough to create a new type of teachers as the key to scientific design work Square practice teaching content and process as the basic content, the elements of mutual cooperation, co-operation.

\section{References}

[1] Zhang Jing Dan. China's graphic design, how to "die" [J]. Art observation. 2013 (07)

[2] Wang Jinfeng. Research on the development trend of visual communication design in the new media era [J]. Popular Literature. 2012 (10)

[3] Yang Lei. Art design professional education research and exploration [J]. Journal of Jilin Province Education College (Late). 2012 (01)

[4] Xia Yanjing. Hook and restore: the history of Chinese contemporary art of multi-vision integration [J]. Art 100. 2012 (01)

[5] Ma Jianxin. Contemporary visual culture to the aesthetic design of graphic design [J]. Literary Contention. 2011 (10)

[6] He Fang. Contemporary Chinese graphic design concepts and teaching changes [J]. Art. 2010 (S2) 